\section{Application of Group Positive Psychotherapy(GPPT) to Increasing Well Being in Women with Systemic Lupus Erithematosus (SLE)}

\author{
Auliya Ulil Irsyadiyah, Ahmad Gimmy Prathama \\ Siswadi, Nurul Wardhani \\ Fakultas Psikologi Universitas Padjajaran \\ Jatinangor, Indonesia 45363 \\ Email : auliyaulilirsyadiyah@gmail.com
}

Journal PSIKODIMENSIA

Volume 18, No. 2,

Juni - Desember 2019

ISSN cetak : 1411-6073

ISSN online : 2579-6321

DOI:10.24167/psidim.v18i2.2247

\begin{abstract}
Systemic Lupus Erithematosus (SLE) is a chronic autoimmune disorder that can affect almost all organs of the body. SLE is part of the chronic illness disabilities (CID) with the highest number of women reproductive age. Not only the physical affects but also quite disturbing psychological conditions, for example increased negative emotions, depression, and suicidal ideation. Chronic illness disabilities (CID) patients often have low perception of life satisfaction and will affect a person's level of well-being. To achieve the condition of well-being, psychological interventions that can help increase the level of well-being in women with Systemic Lupus Erithematosus are needed. The intervention was a group positive psychotherapy by pleasent life, engaged life and meaning full life. The purpose of this research can help individuals to improve well-being especially for women with Systemic Lupus Erithematosus. In this research, Group Positive Psychotherapy was conducted in 14 sessions with pre-test and post-test. This research is a case study with a single case experimental design. The method used is mixed method with concurrent embedded strategy, using qualitative data as primary and quantitative data as secondary data. The measuring instrument used is The PERMA Profiler with a reliability value of 0,761 compared to Cronbach's Alpha which is $r<0,6$ not reliable and $r>0,6$ reliable. The participants in this study were 3 people. Based on qualitative results indicate that there is an increase in the level of wellbeing in the 3 participants and increasing score in 5 aspects of well-being after intervention.
\end{abstract}

Keywords : Chronic Illness Disabilities (CID); Group Positive Psychotherapy; Systemic Lupus Erythematosus; Well Being.

\section{PENDAHULUAN}

Systemic Lupus Erythematosus (SLE) atau biasa disebut dengan Lupus merupakan penyakit kronis yang saat ini berkembang dengan pesat, namun belum banyak mendapat perhatian. New York State Department of Health (2008) mendefinisikan Lupus sebagai suatu gangguan autoimun kronis yang dapat mempengaruhi hampir semua organ tubuh. Systemic Lupus Erythematosus atau biasa disingkat SLE merupakan salah satu jenis Lupus yang tergolong memiliki tingkat keparahan yang paling tinggi. American College of Rheumatology (ACR) menetapkan sebelas kriteria untuk menetapkan diagnosis SLE. Empat kriteria yang pertama berkaitan dengan kulit: sensitivitas terhadap sinar matahari, penyakit mulut, butterfly rash (ruam berbentuk kupu-kupu), dan luka discoid (menyerupai cakram). Empat kriteria yang kedua dikaitkan dengan beberapa organ tubuh tertentu: kelainan pada jantung dan paru- paru, ginjal, sistem 
saraf pusat dan tulang sendi. Tiga kriteria yang tersisa berkaitan dengan kelainan pemeriksaan laboratorium: perubahan jumlah darah (kekurangan sel darah merah, sel darah putih maupun trombosit), hasil tes ANA (antinuclear antobidy) positif, dan kelainan antibodi darah lainnya pada penyakit ini (Wallace, 2007). Adapun bagi para penderita Lupus biasa disebut dengan Odapus (Orang dengan Lupus).

Yayasan Lupus Indonesia (2011) mencatat sejak 1998 hingga 2008 odapus semakin meningkat hingga mencapai angka 9000 penderita. Jumlah penderita wanita 10 kali lebih banyak dibandingkan laki-laki dengan usia yang rentan adalah usia produktif (Yayasan Lupus Indonesia, 2011). Sementara berdasarkan Kementrian kesehatan (2011) mencatat bahwa di Indonesia, jumlah penderita penyakit Lupus secara tepat belum diketahui, diperkirakan mencapai jumlah 1,5 juta orang. Organisasi Kesehatan Dunia atau WHO mencatat jumlah penderita penyakit Lupus di seluruh dunia dewasa ini mencapai lima juta orang. Prevalensi pada berbagai populasi berbeda-beda bervariasi antara $300-400$ orang per 100 ribu penduduk (Kemenkes, 2011). Tingginya kematian akibat Lupus ini perlu mendapat perhatian khusus karena sekitar 25\% dari pasien rawat inap di rumah sakit di Indonesia tahun 2016 berakhir kematian. Banyaknya penderita Lupus yang terjadi pada wanita sesuai dengan apa yang diungkapkan oleh Wallace (2007) bahwa berdasarkan penyebaran usia pada anak-anak dan orang dewasa di atas usia 50 tahun, timbulnya Lupus menunjukkan hanya sedikit kecenderungannya pada perempuan, tetapi antara umur 15 sampai 45 tahun hampir $90 \%$ pengidapnya adalah perempuan.

Perbedaan hormonal antara pria dan wanita mungkin menjadi latar belakang timbulnya Lupus. Wanita memiliki hormon estrogen yang dihasilkan oleh indung telur (ovarium). Penelitian eksperimental pada tikus menunjukkan bahwa esterogen dapat mencetuskan kondisi penyakit yang serupa dengan Lupus pada manusia. Peningkatan kadar esterogen dimulai ketika seorang wanita memasuki masa reproduksi yang ditandai dengan datangnya menstruasi yang pertama kali (menarche) dan berkurang ketika menstruasi berhenti (menopause). Kebanyakan para ahli setuju bahwa hormon estrogen merupakan predisposisi terhadap autoimunitas. Penelitian Dr. Vrigina Rider dari Universitas Pittburgh menyimpulkan bahwa estrogen dapat merubah ekspresi gen pada limfosit dari pasien yang menderita Lupus, tetapi tidak ada pada orang normal.

Ketika orang dengan Systemic Lupus Erythematosus mengalami kekambuhan, maka gejala fisik yang muncul adalah kelelahan yang luar biasa, perubahan berat badan, bercak merah pada wajah yang berbentuk seperti kupu-kupu, sakit kepala, anemia, sensitif terhadap sinar matahari, rambut rontok, ujung jari berwarna kebiruan/ pucat nila kedinginan dan mouth/ nose ulcers. Selain gejala fisik yang pada akhirnya menghambat aktivitasnya sehari-hari, Odapus SLE juga melaporkan adanya gejala psikologis dan psikiatris seperti psikosis, depresi, kecemasan, gangguan emosi lainnya: stress dan anger, emotional distress, feeling of uncertainly, ketidakberdayaan, lack of control kehilangan rasa percaya diri dan takut akan kematian.

Pada penelitian mengenai depresi pada pasien Systemic Lupus Eritematosus (SLE) yang dilakukan oleh Schattner, Shahr, Lerman dan Shakra (2010) menyimpulkan bahwa depresi yang dialami oleh pasien tidak disebabkan oleh penyakit Systemic Lupus Eritematosus itu sendiri, melainkan disebabkan oleh faktor lain 
yaitu illness intrusiveness. Illness intrusiveness meliputi keadaan yang mengganggu akibat dari penyakit dan pengobatan yang dijalani pasien yang menyebabkan gangguan atau hambatan pada gaya hidup, aktivitas yang berharga dan minat. Hal ini juga perlu dijadikan sebagai pertimbangan untuk menggambarkan dinamika psikologis yang terjadi pada Odapus $S L E$.

Tam, dkk (dalam NavarreteNavarrete, dkk., 2010) menunjukkan bahwa depresi dan kecemasan merupakan variabel independen yang mempengaruhi fungsi fisik dan mental pada Odapus SLE. Kecemasan adalah salah satu gejala neuropsikiatri paling umum pada Odapus dan dikaitkan dengan rendahnya kualitas hidup Odapus SLE. Odapus SLE mengalami kecemasan ketika mereka menganggap penampilan mereka menjadi suatu masalah.

Taylor (dalam Sutisna, 2010) mengartikan stres sebagai emosi-emosi negatif yang disertai dengan gejalagejala biokimia, fisiologis, kognitif serta perubahan perilaku yang mengacu pada stresor. Stres juga merupakan pemicu aktifnya Lupus, hal ini ditunjukkan oleh penelitian yang melibatkan 58 pasien Lupus, hasilnya menunjukkan bahwa stres sehari-hari secara signifikan memprediksi peningkatan simptom klinis Lupus pada $74,1 \%$ jumlah pasien (Peralta-Ramirez dalam NavarreteNavarrete, dkk., 2010).

Bukan hanya mengalami emosi negatif yang berkepanjangan, namun berbagai penelitian menunjukan bahwa orang yang terganggu domain kesehatan-nya, yang mana ia memiliki chronic illness disabilities (CID), dimana Lupus termasuk di dalamnya, seringkali memiliki persepsi kepuasan hidup yang rendah dibanding dengan mereka yang tidak memiliki CID (Dijkers, 1999: Krause, 1992 dalam Kim, Berven, Chan, Gonzalez, Miller, dan Keck, 2011). Munculnya afek negatif dan minimnya afek positif pada Odapus SLE serta ketidakpuasan terhadap hidup bagi penyandang chronic illness dimungkinkan akan mempengaruhi well being seseorang.

Berdasarkan data yang diperoleh bahwa diketahui diagnosa lupus umumnya banyak terjadi pada wanita usia produktif. Hal ini tentu menjadi kekhawatiran tersendiri bagi para wanita. Seperti kita ketahui bahwa di era saat ini keberfungsian wanita tidak kalah penting dengan peran laki-laki, misalnya dalam hal tuntutan pekerjaan. Ketika seorang wanita didiagnosa sebagai Odapus SLE, tentu akan mengganggu keberfungsian dan rutinitas kehidupannya, sehingga dimungkinkan juga akan mempengaruhi tingkat kesejahteraan hidupnya.

Menurut Seligman (2011) wellbeing bukanlah sesuatu yang hanya ada di dalam pikiran individu, tetapi merupakan kombinasi dari perasaan baik mengenai diri sendiri dan perasaan memiliki makna hidup, pencapaian dan hubungan yang baik dengan orang lain. Seligman juga menjelaskan well-being sebagai suatu konstruk yang terdiri dari lima elemen yaitu positive emotion $(P)$, engagement $(E)$, relationships $(R)$, meaning $(M)$, dan accomplishment $(A)$ yang dapat diukur secara subjektif dan objektif. Semua perilaku manusia mengarah kepada peningkatan kelima elemen tersebut yang disingkat sebagai PERMA. Peningkatan dari PERMA akan mengarah kepada tingkat well-being yang tinggi yang disebut sebagai flourishing, yaitu kombinasi dari perasaan yang menyenangkan (good feeling) dengan fungsi yang baik (wellfunctioning) secara psikis dan sosial (Huppert, 2013).

Mengingat pentingnya penanganan secara dini terkait dengan kesehatan psikis dari odapus maka dibutuhkan sebuat intervensi untuk memunculkan emosi dan kenangan positif yang pernah dialami dari Odapus 
SLE wanita. Hal tersebut dilakukan dengan memunculkan kekuatan karakter dan kebermaknaan dengan cara membangun hidup yang menyenangkan (pleasent life), hidup yang mengikat pada aktivitas (engaged life) dan hidup yang bermakna (pursuit of meaning) untuk mengatasi hal-hal ataupun emosiemosi negatif saat ini yang muncul. Hal tersebut bertujuan untuk membangun well being pada pasien Odapus SLE wanita, sehingga harapannya mereka dapat menjalankan kehidupannya secara lebih produktif dan dapat mengurangi stress psikologis yang dialami.

Positive

psychotherapy merupakan pendekatan psikoterapi yang dapat membangun kekuatan dan emosi positif klien. Pendekatan ini menitikberatkan pada keterlibatan individu dalam meningkatkan emosi, pikiran dan perilaku positif. Positive psychotherapi adalah pendekatan psikoterapi yang telah divalidasi secara empiris untuk membangun kekuatan klien dan emosi positif, dan meningkatkan makna kehidupan klien dalam usahanya mengurangi psikopatologi dan meningkatkan kebahagiaan (Rashid \& Seligman, 2018). Positive psychotherapy didasarkan pada konseptualisasi Seligman tentang kesejahteraan (well being) (Rashid \& Seligman 2018). Seligman menguraikan kesejahteraan (well being) menjadi komponenkomponen ilmiah yang terukur dan dikelola seperti emosi positif, engagement, relationships, meaning and accomplishment (Rashid \& Seligman 2018).

Penerapan positive psychotherapy tidak hanya dapat diaplikasikan pada individual tetapi juga kelompok (Park, Peterson \& Seligman, 2009). Mereka dilatih untuk membantu diri mereka dan melibatkan satu sama lain (Park, Peterson \& Seligman, 2009). Group psychotherapy merupakan bentuk psikoterapi di mana terapis memberikan intervensi pada sekelompok klien secara bersama-sama sebagai sebuah kelompok. Group psychotherapy dapat membantu memecahkan permasalahan emosional dan membangun kekuatan karakter (character strength).

Intervensi dengan pendekatan positive psychotherapy akan dilakukan dalam bentuk group. Group therapy sangat membantu dengan memecahkan kesulitan-kesulitan emosional, membangun kekuatan karakter dan kebermaknaan pribadi peserta dalam group. Pada pelaksanaannya Group therapy setiap individu akan membagikan perasaan dan pikirannya, memberikan umpan balik, serta memberikan dukungan atau kritik antar individu. Group therapy memberikan kesempatan untuk belajar tentang masalah seseorang dalam hubungan sosial, belajar bagaimana individu lain di dalam kelompok dalam kaitannya dengan problem solving atas masalahnya, dan juga berguna untuk meningkatkan self esteem (Yalom, dalam Bieling, McCabe \& Antoni, 2006).

Peneliti menggunakan pendekatan group therapy karena adanya peran teman atau beberapa penderita Odapus yang memiliki permasalahan yang sama di dalam satu komunitas yang dinamakan dengan "Panggon Kupu" yang berada di bawah naungan Yayasan Lupus Indonesia. Keunggulan dari pemberian intervensi dengan pendekatan kelompok adalah kelompok dapat menjadi agent of change, mendapat dukungan sosial, saling berbagi pengalaman dan solusi masalah di dalam kelompok sehingga diharapkan lebih sering memunculkan insight pada masing-masing individu sehingga diharapkan dapat meningkatkan well being yang rendah pada Odapus SLE wanita usia produktif.. 


\section{METODE}

Penelitian ini merupakan penelitian studi kasus, yang bertujuan untuk mengetahui efektivitas dari pemberian intervensi psikologis berupa group positive psychotherapy untuk membantu meningkatkan well-being pada penyandang Systemic Lupus Erythematosus. Dibutuhkan pemahaman pada masing-masing kasus untuk memahami konsep well-being, karena konsep tersebut pada seseorang tergantung pada pribadi masing-masing individu yang mengalami meskipun terdapat beberapa elemen yang dapat diukur secara objektif bukan hanya dari sudut pandang pribadi.

Metode yang digunakan yaitu mix method dengan concurrent embedded strategy. Creswell (2010) mengemukakan bahwa concurrent embedded strategy adalah sebuah metode strategi campuran yang memiliki metode primer dan sekunder dalam menerapkan sebuah data. Data primer merupakan data utama dari penelitian sedangkan data sekunder adalah pendukung dalam prosedur penelitian. Proses penggunaan data primer dan sekunder adalah peneliti mengomparasikan suatu sumber data dengan sumber data yang lain atau mendeskripsikan kedua sumber data secara berdampingan dalam pembahasan penelitian. Creswell (2010) menjelaskan bahwa strategi concurrent embedded strategy dilakukan agar peneliti tidak hanya menggunakan metode yang dominan, namun menggunakan dua metode yang berbeda. Tujuannya adalah untuk mendapatkan perspektif yang lebih luas.

Rancangan penelitian yang digunakan menggunakan single case experimental design. Desain eksperimen kasus tunggal (single-case experimental design) merupakan sebuah desain penelitian untuk mengevaluasi efek suatu perlakuan (intervensi) dengan kasus tunggal. Teknik sampling yang digunakan dalam penelitian ini adalah purposive sampling, yaitu sebuah strategi untuk menentukan partisipan yang berdasarkan pada kriteria-kriteria tertentu yang telah dibuat terhadap obyek yang sesuai dengan tujuan penelitian (Sugiyono, 2012). Adapaun kriteria yang dimaksud adalah wanita usia 20-40 tahun yang didiagnosis oleh dokter sebagai odapus SLE, lama diagnosa tidak lebih dari 10 tahun, memiliki tingkat well being dalam kategori rata-rata atau rendah dengan skala PERMA Profiler, berada dalam kondisi yang memungkinkan sebagai subjek penelitian dan bersedia mengikuti sesi intervensi sampai selesai dengan mengisi inform consent penelitian.

Metode pengumpulan data menggunakan instrumen pengukuran yaitu The Perma Profiler (Butler dan Kern, 2016) untuk mengukur 5 dimensi well being secara keseluruhan. Alat ukur ini memiliki 23 aitem pertanyaan dan menggunakan tiga jenis pilihan respon. Masing-masing jenis pilihan respon memiliki rentang nilai dari 0 sampai dengan 10. Adapun jenis rentang yang digunakan dalam alat ukur ini adalah Tidak Pernah - Selalu, Sangat Buruk Sangat Baik, dan Tidak Sama Sekali Sepenuhnya. Dalam penelitian ini, peneliti mencoba untuk melakukan kembali uji reliabilitas kepada 60 responden wanita odapus SLE usia 2040 tahun. Selanjutnya reliabilitas alat ukur dilihat melalui konsistensi melalui analyze scale reliability untuk menentukan reliabel atau tidaknya alat ukur, maka reliabilitas dibandingkan dengan kriteria dari Cronbach (1993) yaitu $r<0,6$ tidak reliabel dan $r>0,6$ reliabel. Pada hasil perhitungan yang telah dilakukan peneliti, menunjukkan skor Alpha 0,761 yang berarti cukup reliabel.

Metode pengambilan data yang selanjutnya adalah wawancara. Menurut Moleong (2011) wawancara adalah percakapan dengan maksud tertentu, 
yang dilakukan oleh dua pihak, yaitu pewawancara (interviewer) yang mengajukan pertanyaan dan terwawancara (interviewee) yang memberikan jawaban atas pertanyaaan. Metode yang digunakan peneliti adalah wawancara semi-terstruktur. Wawancara semi-terstruktur memiliki ciri-ciri yaitu: a) pertanyaan terbuka, namun ada batasan tema dan alur pembicaraan; b) kecepatan wawancara dapat diprediksi c) fleksibel, tetapi terkontrol (dalam hal pertanyaan atau jawaban); d) ada pedoman wawancara yang dijadikan patokan dalam alur, urutan, dan penggunaan kata; e) tujuan wawancara adalah untuk memahami suatu fenomena. Guide interview disusun berdasarkan aspek well-being dan dapat dikembangkan sesuai dengan kebutuhan dalam proses pengambilan data.

Metode pengumpulan data yang ketiga menggunakan observasi. Observasi merupakan suatu proses kompleks dan tersusun dari berbagai proses biologis dan psikologis yang di dalamnya terdapat proses-proses pengamatan dan ingatan (Sugiyono, 2012). Peneliti dapat merekam ataupun mencatat pengamatan yang telah dilakukan, baik dengan cara terstruktur maupun semi terstruktur (Creswell, 2010). Penelitian ini juga dibantu dengan co-fasilitator, sehingga data observasi yang diperoleh akan lebih objektif.

Pada penelitian ini pengukuran dengan menggunakan alat ukur The Perma Profiler dilakukan sebelum dan sesudah rangkaian terapi diberikan seluruhnya. Selain itu juga dilakukan wawancara sebelum dan setelah dilakukan intervensi. Hasil pengukuran tersebut akan dipaparkan dengan diagram batang. Untuk memahami kondisi well being sebelum dan setelah dilakukan sesi terapi beserta perubahannya akan dijelaskan dengan metode deskriptif. Adapun norma digunakan untuk mendeskripsikan kondisi well being adalah norma kelompok yang dibagi menjadi beberapa kategori. Sementara Rashid \& Seligman (2018) memiliki kategorisasi skor untuk masing-masing aspek well being.

Selain itu digunakan pendekatan kualitatif yang digunakan untuk memahami proses yang terjadi dalam diri individu atas pemberian tiap sesi terapi. Data yang digunakan untuk membahas perubahan kondisi well being setiap partisipan adalah melalui worksheet terapi, wawancara dan juga proses diskusi yang berjalan dari setiap sesi terapi. Penarikan kesimpulan terhadap data kualitatif akan mengacu pada dua sumber teori yaitu well being yang dikemukakan Seligman dan juga teori-teori dasar tentang group positive psychotherapy yang dirancang oleh Rashid (dalam Magyar-Moe, 2009).

Berdasarkan yang diungkapkan oleh Rashid \& Seligman (2018), positive psychotherapy idealnya dilakukan dalam 14 sesi yang setiap sesinya akan membahas tema dan konstruk psikologi positif yang berbeda. Peneliti melakukan dalam 14 sesi terapi untuk melihat lebih comprehensif pengaruh group positive psychotherapy pada Odapus SLE wanita. Selain itu disediakan pula tugas rumah yang harus dikerjakan oleh subjek/ partisipan. Rashid \& Seligman (2018) juga mengungkapkan bahwa setiap tugas dan banyaknya sesi terapi juga disesuaikan dengan kebutuhan subjek/ partisipan.

\section{HASIL}

Penelitian ini dilakukan untuk mengetahui efek group positive psychotherapy terhadap well-being pada odapus (orang dengan lupus) SLE (systemic lupus eritematosus). Data kuantitatif dalam penelitian ini adalah hasil pengukuran tingkat well-being menggunakan skala The PERMA Profiler. Skala tersebut diberikan pada pre-test dan post-test kepada ketiga subjek penelitian. Untuk melihat hasil 
perbedaan dari pengukuran skala PERMA pada ketiga subjek, disajikan dalam bentuk diagram batang berikut :

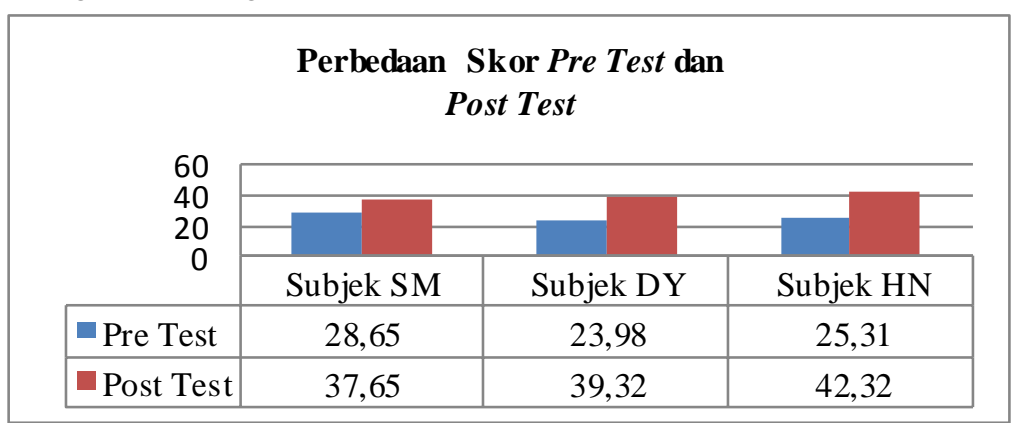

Grafik 1.1 Skor Pre Test dan Post Test Tingkat Well-being Berdasarkan PERMA

Perubahan skor pre-test dan post-test pada ketiga subjek mengalami peningkatan. Artinya adanya peningkatan well being yang dialami oleh ketiga subjek dari sebelum dan setelah dilakukan intervensi berupa
GPPT. Pada subjek SM terlihat adanya peningkatan skor well-being sebesar 9 poin dari skor sebelum dilakukan intervensi yaitu 28,65 (average) dan setelah dilakukan intervensi meningkat menjadi 37,65 (slightly above average).

\section{Subjek SM}

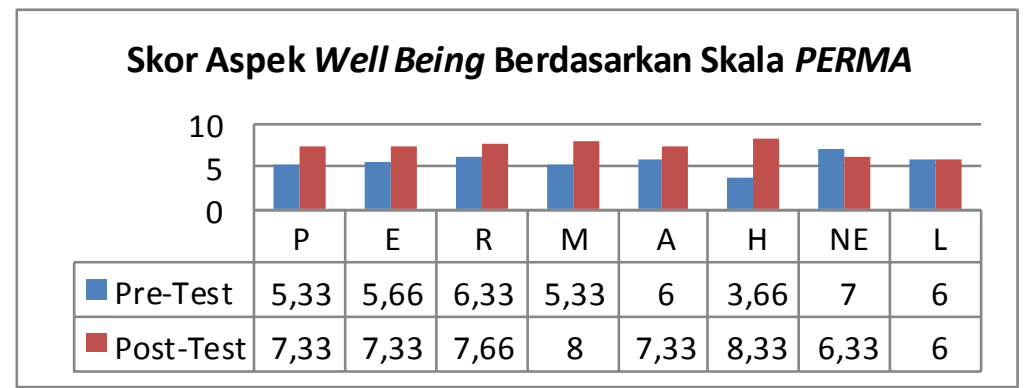

Grafik 1.2 Perbedaan Skor Pre-Test dan Post-Test pada Subjek SM

Pada subjek DY terlihat peningkatan skor well-being sebesar 15,34 poin, dari 23,98 (kategori average) menjadi 39,32 (kategori high), sedangkan pada subjek HN mengalami peningkatan skor sebesar 17.01 poin dari 25,31 (kategori average) menjadi 42,32 (kategori high)..

\section{Subjek DY}

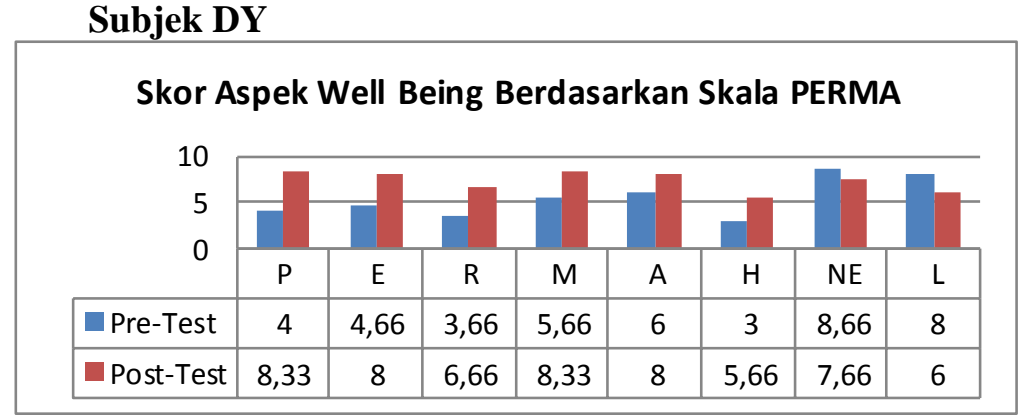

Grafik 1.3 Perbedaan Skor Pre-Test dan Post-Test pada Subjek DY 
Dari ketiga subjek tersebut dapat dilihat bahwa peningkatan tertinggi dialami oleh HN dan skor peningkatan terendah dialami oleh SM. Pada masing - masing aspek juga terlihat perbedaan skor pretest dan post-test

\section{Subjek HN}

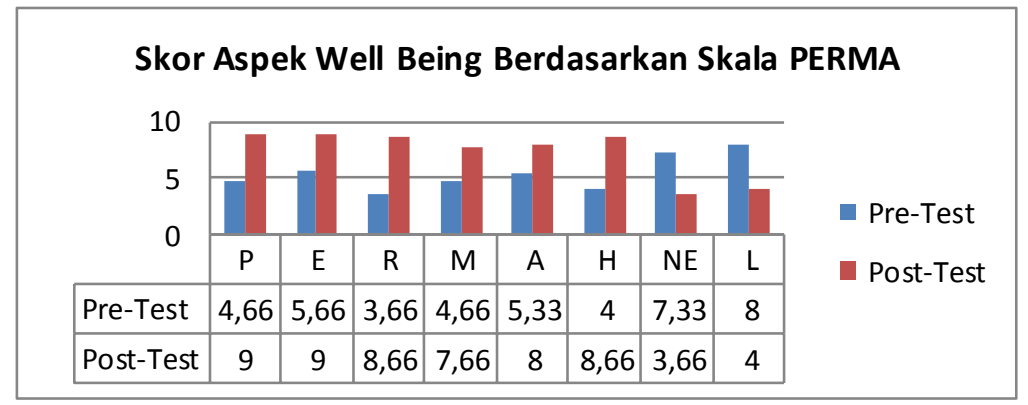

Grafik 1.4 Perbedaan Skor Pre-Test dan Post Test pada Subjek HN

Secara lebih detil peningkatan skor juga terjadi pada semua aspek wellbeing dan penurunan skor pada aspek tambahan yaitu negative emotion dan lone kecuali pada subjek SM. Penjelasan tersebut juga dididukung oleh data kualitatif yang menunjukkan lebih banyak perubahan ke arah positif yang dirasakan oleh ketiga subjek setelah mengikuti intervensi berupa group positive psychotherapy.

\section{DISKUSI}

\section{Positive Emotion}

Sebelum intervensi dilakukan kedua subjek yaitu DY dan HN mengalami perasaan kecewa, sedih, dan marah akan diagnosa lupus yang ada pada dirinya. Melalui keikutsertaannya dalam intervensi group positive psychotherapy sebanyak 14 sesi, terlihat bahwa terdapat perbedaan sudut pandang dari kedua subjek terkait kondisi dirinya sebagai odapus. Kedua subjek mulai bisa memberikan pandangan positifnya untuk menerima diagnosa dirinya sebagai odapus. Hal ini sesuai dengan yang dikemukakan oleh Seligman (2011), bahwa emosi positif di masa lalu meliputi penerimaan, kepuasan, pemenuhan, kebanggaan dan ketenangan.
Emosi negatif yang dirasakan oleh kedua subjek, berbeda dengan emosi negatif pada SM. Ia mengeluhkan bahwa muncul rasa bosan dan jenuh karena setiap hari ia harus minum obat. Selain itu perasaan cemas terus menghantuinya karena pengalaman tetangga yang meninggal karena lupus. Meski sudah 8 tahun ia didiagnosa lupus, perasaan takut meninggal terus muncul. Terlebih ketika ia sedang mengalami flare, ia merasa semakin khawatir. Hal ini serupa dengan pernyataan Tam, dkk (dalam Navarrete-Navarrete, dkk., 2010) yang menunjukkan bahwa depresi dan kecemasan merupakan variabel independen yang mempengaruhi fungsi fisik dan mental pada Odapus SLE.

Positivie psychotherapy juga memodifikasi harapan dan optimisme untuk melawan kondisi pesimistik yang ada (Seligman, 2011). Mengembangkan rasa syukur dan berlatih untuk memaafkan juga dapat meningkatkan emosi positif. Hal ini sesuai dengan data kualitatif yang diperoleh berdasarkan proses terapi yang dilakukan. Kedua subjek DY dan HN berlatih untuk memaafkan kesalahan yang pernah dilakukan oleh diri sendiri maupun orang lain dengan cara menuliskan forgiveness letter. Setelah dilakukan 
evaluasi terkait emosi apa yang dirasakan setelah menulis surat tersebut, kedua subjek merasa lebih lega dan tenang. Selain itu, kedua subjek juga belajar tentang rasa syukur.

Manfaat dari kelompok salah satunya adalah membandingkan kondisi diri dengan kondisi orang lain, yang ternyata oleh kedua subjek dimaknai bahwa setiap orang memiliki masalah dan keinginan yang tidak selalu bisa terpenuhi. Hal ini menjadikan kedua subjek justru lebih optimis dalam menjalani hidupnya. Uraian tersebut diatas sejalan dengan perolehan skor pre-test dan post-test yang memiliki peningkatan pada aspek positive emotion dan penurunan pada aspek negative emotion.

\section{Engagement}

Aspek engagement pada ketiga subjek mengalami peningkatan. Menurut Seligman (2011) engagement mengarah kepada keterlibatan, ketertarikan dan menyatu dengan suatu kegiatan atau aktivitas. Pada proses terapi yang dilakukan tema engagement terus dibawa mulai dari awal hingga akhir sesi. Sampai akhirnya kedua subjek yaitu DY dan HN dapat merencanakan kegiatan yang melibatkan diri di dalamnya bersama dengan orang-orang terdekat yang dikehendaki.

Jika sebelumnya ada kemalasan untuk melakukan kegiatan di luar rumah, kedua subjek terlihat mulai menikmati kegiatan yang dilakukan bersama orang terdekat. Didukung dengan hasil observasi yang dilakukan selama kedua subjek menceritakan pengalamannya, terlihat raut wajah kegembiraan. Hal ini sejalan dengan perubahan skor pada aspek engagement yang mengalami peningkatan sebesar 3,34 poin pada subjek DY dan HN.

Berbeda halnya dengan subjek SM. Subjek SM merupakan salah satu subjek yang tidak mengikuti sesi intervensi hingga akhir (sesi 14). SM hanya mengikuti intervensi hingga sesi ke X. Hal ini ternyata mempengaruhi pada skor engagement yang mengalami peningkatan paling rendah diantara keduanya, yaitu sebesar 1,67 poin. Sejalan dengan hasil kualitatif yang diperoleh bahwa ia masih merasa jauh dengan anaknya. Pekerjaan yang cukup menyita waktu bahkan saat weekend. Ia hampir tidak pernah benar-benar meluangkan waktu dengan anak ataupun keluarga untuk liburan bersama. Ia merasa belum bisa memberikan waktunya untuk menemani anakanaknya berlibur sekalipun anak-anak sudah memintanya. Menurutnya dengan ia bekerja dan mendapatkan uang yang cukup, menjadi cara untuk dapat membahagiakan anak-anaknya karena dapat memenuhi keinginan anak serta membiayai sekolah anaknya.

\section{Relationships}

Selanjutnya terlihat pula bahwa aspek ketiga pada ketiga subjek mengalami perubahan. Aspek ketiga, yaitu relationship adalah perasaan dicintai, didukung, dan dihargai oleh orang lain. Memiliki hubungan positif dengan orang lain dapat membuat individu merasa lebih baik (Seligman, 2011). Kesejahteraan atau well-being dapat meningkat dengan memiliki hubungan yang kuat dengan keluarga, teman, teman kerja ataupun tetangga. Terdapat hubungan yang membaik dari kedua subjek. Muncul perasaan bahwa keluarga memberikan perhatian, keluarga yang peduli terhadapnya, keluarga yang mencintainya, anak, suami, dan orangtua yang menyayangi. Hubungan bermasyarakat juga semakin membaik, tidak lagi malas jika bertemu orang, malu dengan kondisi diri, tidak percaya diri dan menjadi lebih mengerti manfaat memiliki teman untuk saling berbagi. Hal ini sejalan dengan perubahan skor yang juga mengalami peningkatan pada aspek relationship dari pre-test dan post-test.

\section{Meaning}


Meaning atau makna hidup berarti merasa memiliki tujuan di dalam hidup, merasa hidup itu berharga atau merasa memiliki hubungan dengan sesuatu yang lebih besar daripada diri kita seperti kepercayaan religius (Seligman, 2011). Terlihat dari skala PERMA bahwa aspek meaning memiliki peningkatan skor pretest dan post-test. Pemaknaan yang dilakukan oleh ketiga subjek adalah munculnya rasa bersyukur atas kondisi diri dan meyakini bahwa kondisinya saat ini sudah ada yang mengatur. Cavis (2015) menyatakan bahwa adanya makna spiritualitas dan keagamaan dapat membantu individu yang mengalami masa-masa sulit dapat berkembang dalam proses penyembuhannya. Ketiga subjek justru mengalami kedekatan dengan Tuhan setelah didiagnosa lupus, meski awalnya sempat menyalahkan ketetapan Tuhan atas kondisi dirinya. Namun saat ini keduanya terlihat memiliki kedekatan yang cukup kuat dengan Tuhan. Terlihat beberapa kali saat mengungkapkan pendapat memberikan pernyataan bahwa apapun yang terjadi dalam hidupnya semua dikembalikan kepada Tuhan.

Bukan hanya terkait dengan spiritualitas, namun juga keberhargaan diri. Pada sesi-sesi akhir proses terapi dilakukan subjek DY dan SM merasa bahwa keberadaanya penting bagi orang yang mencintai dan menyayanginya. Muncul rasa optimisme dan semangat untuk menjalani hidup karena merasa dirinya dibutuhkan oleh orang terdekat. Rasa putus asa karena sakit yang tidak kunjung sembuh dimaknai dengan hal yang berbeda oleh kedua subjek. Keduanya memaknai sakit lupus sebagai bentuk peringatan agar lebih bersyukur dan mendekatkan diri dengan Tuhan. Berbeda halnya dengan SM, bahwa pada awal sesi, ia sudah mengutarakan bahwa keberadaanya penting bagi anak-anak dan suaminya, ia merasa keluarga masih membutuhkannya, ia juga memiliki semangat untuk terus bekerja untuk biaya sekolah anak-anaknya, sehingga ketika di akhir sesi intervensi ia tidak mengikuti, namun perasaan tersebut sudah muncul pada sesi awal intervensi di lakukan pada saat diskusi terkait dengan tema pemanfaatan strength yang dimiliki.

\section{Accomplishment}

Accomplishment

adalah pencapaian yang diraih oleh individu. Pencapaian dapat bersifat objektif, seperti menerima sebuah penghargaan, merasa mahir dalam sesuatu juga berperan penting untuk dimensi ini. Skala ini mengukur perasaan subjektif dari pencapaian, seperti merasa mampu untuk menyelesaikan tugas dan mengerjakan sesuatu untuk mencapai tujuan. Berbagai penelitian menunjukan bahwa orang yang terganggu domain kesehatan-nya, yang mana ia memiliki chronic illness disabilities (CID), dimana Lupus termasuk di dalamnya, seringkali memiliki persepsi kepuasan hidup yang rendah dibanding dengan mereka yang tidak memiliki CID (Dijkers, 1999: Krause, 1992 dalam Kim, Berven, Chan, Gonzalez, Miller, dan Keck, 2011). Artinya terdapat rasa ketidakpuasan atas apa yang diperoleh. Systemic Lupus Eritematosus merupakan penyakit kronis yang menyebabkan seseorang merasa sakit, rendah diri, terbatas kemampuan dan aktivitasnya. Pada aspek ini, ketiga subjek mengalami peningkatan skor yang paling rendah dibandingkan peningkatan skor pada aspek yang lain. Meskipun demikian dari data kualitatif yang didapatkan, terlihat adanya perubahan sudut pandang dari kedua ketiga subjek terkait rasa bersyukur, sehingga tidak lagi terlalu fokus pada hal yang belum bisa dirah namun fokus pada hal yang sudah dimiliki.

Dari ketiga subjek, terlihat bahwa SM merupakan subjek yang memiliki skor pre-test tertinggi, namun mengalami peningkatan skor dengan poin terendah dibandingkan dengan 
kedua subjek lain. Hal ini dikarenakan tidak maksimalnya SM dalam mengikuti semua sesi intervensi. Aspek yang paling menonjol dengan peningkatan skor terendah adalah engagement dan relationship. Hal ini sejalan dengan proses intervensi yang tidak dijalani oleh SM (S1) mulai dari sesi XI - XIV. Dapat dilihat bahwa materi diskusi dan tugas yang diberikan pada sesi XI - XIV berkaitan dengan aktivitas menyenangkan dan keterlibatannya di dalam aktivitas tersebut bersama dengan orang terdekat serta ia dapat memberikan waktunya untuk menyenangkan orang lain. Tugas-tugas tersebut dimulai dari identifikasi strength yang dimiliki oleh keluarga, menemukan hobby dan menikmati hobby yang dilakukan, merencanakan kegiatan yang menyenangkan bersama keluarga dan juga melakukannya. Materi tersebut tidak diikuti oleh SM (S1) yang ternyata mempengaruhi peningkatan skor pada aspek engagement dan relationship yang kurang maksimal.

Berdasarkan penelitian yang dilakukan bahwa Positive Psychotherapy dapat dibagi menjadi tiga fase. Fase yang pertama berfokus pada eksplorasi narasi yang seimbang dari klien dan eksplorasi signature strength dari berbagai perspektifnya. Kemudian signature strength dioperasionalkan ke dalam tujuan yang bermakna secara pribadi. Fase kedua, berfokus pada menumbuhkan emosi positif dan secara adaptif menghadapi ingatan negatif. Fase terakhir meliputi latihan untuk membina hubungan positif dan bermakna serta membuat tujuan. Pada sesi-sesi terapi yang dijalani akan mengajarkan kembali klien untuk mengingat atau memperhatikan hal-hal positif yang dialami oleh klien semasa hidupnya. Contoh ketika diberikan tugas untuk menuliskan 3 hal positif yang dialami setiap hari, meniadakan kecenderungan untuk merenungi hal-hal negatif yang menimbulkan depresi.
Latihan bersyukur, misalnya akan melatih klien untuk merubah kenangan dari adanya aspek kebencian dari pengalaman yang tidak menyenangkan. Mulai dari sesi awal pada group psychotherapy klien didorong untuk mengeksplorasi kekuatan mereka dan atribut positif lainnya.

Positive psychotherapy tidak hanya dapat dilakukan secara individual, namun juga kelompok. Pada penelitian ini, terlihat bahwa terapi yang dilakukan dalam bentuk kelompok lebih banyak mendapatkan manfaat. Masing-masing subjek dapat mendapatkan insight dari proses diskusi yang dilakukan, selain dari tugas-tugas rumah yang diberikan. Selain itu, tidak maksimalnya subjek dalam mengikuti sesi terapi secara keseluruhan (hingga 14 sesi) menjadikan tidak maksimalnya peningkatan skor pada aspek well-being yang berkaitan. Hal ini terlihat ketika subjek SM, hanya mengikuti sesi intervensi hingga sesi $\mathrm{X}$, berkaitan dengan peningkatan aspek engagement dan relationships yang tidak maksimal.

Kuesioner VIA-IS sangat efektif sebagai alat bantu dalam sesi terapi yang kemudian didiskusikan hasilnya untuk mengidentifikasi signature strength subjek. Hal ini menjadikan subjek lebih mengenali diri tentang kelebihannya sehingga dapat digunakan sebagai pintu utama untuk meningkatkan ataupun memunculkan emosi positif dalam diri subjek. Tugas-tugas yang sederhana dan berkaitan dengan kehidupan sehari-hari dirasa tidak membebani subjek, baik untuk mereka dengan tingkat pendidikan rendah maupun tinggi.

Peningkatan skor aspek paling tinggi pada masing-masing subjek berbeda-beda, berdasarkan pengalaman hidup dan insight yang diperoleh selama sesi terapi berlangsung. Aspek yang memiliki peningkatan paling tinggi pada SM adalah kebermaknaan/ Meaning life. Berkaitan dengan kebermaknaannya sebagai seorang istri dan ibu. Sementara 
pada subjek DY peningkatan tertinggi terjadi pada aspek positive emotion.Sedangkan HN kenaikan skor tertinggi dari sebelum dan setelah dilakukan intervensi Group Positive Psychotherapy terletak pada aspek relationship.

Dari ketiga subjek, HN merupakan subjek yang mengalami kenaikan skor well-being tertinggi. Adapun hal ini dipengaruhi oleh kepribadian HN yang cukup terbuka, memiliki semangat yang tinggi setiap mengikuti sesi terapi, kooperatif dengan selalu menjalankan sungguh-sungguh tugasnya, aktif di dalam kelompok bahkan terkadang cenderung menguasai proses diskusi dalam kelompok.

$$
\text { Melalui Group Positive }
$$

Psychotherapy dapat mempercepat peningkatan well-being yang dialami oleh wanita SLE. Jika dilihat pada subjek SM dapat mencapai skor wellbeing dalam kategori average membutuhkan waktu kurang lebih 8 tahun semenjak ia didiagnosa SLE. Sementara dalam waktu 2-3 bulan dilaksanakannya Group Positive Psychotherapy menjadikan well-being pada subjek DY dan HN meningkat cukup signifikan, terbukti dari skor dan hasil wawancara kualitatif yang diperoleh.

\section{SIMPULAN}

1. Group Positive Psychotherapy memberikan efek positif pada peningkatan tingkat well being para subjek, dalam hal ini adalah orang dengan lupus (odapus). Para subjek dapat mengungkapkan peningkatan pada aspek well being, yaitu positive emotion, engagement, relationship, meaning dan accomplishment.

2. Proses intervensi Group Positive Psychotherapy dalam meberikan pengaruh untuk meningkatkan well being adalah sebagai berikut :

a. Penerimaan diri subjek terhadap kondisi saat ini, mengurangi kekecewaan dengan cara memaafkan, bersyukur dan meningkatkan emosi positif serta menurunkan emosi negatif yang ada dalam diri subjek bertujuan untuk membangun hidup yang menyenangkan (pleasent life),

b. Subjek tidak lagi terpaku ataupun larut dalam pengalaman tidak menyenangkan terkait dengan lingkungan, yang sebelumnya dimaknai sebagai hal yang negatif, namun bisa memaknai dari sudut pandang positif, sehingga menjadi terikat dengan lingkungan dan larut dalam aktivitas yang menyenangkan. Hal ini bertujuan untuk membangun hidup yang mengikat pada aktivitas (engaged life.)

c. Menggunakan strength yang dimiliki dan terus digunakan sebagai pengingat bagi subjek bahwa ia memiliki kekuatan atau kelebihan. Harapannya Subjek merasa berharga, merasa memiliki peran yang penting dan bermanfaat. Hal ini bertujuan untuk membangun hidup yang bermakna (pursuit of meaning).

3. Kegiatan bersama dalam kelompok bermanfaat bagi subjek untuk saling memotivasi, mendukung, belajar dari pengalaman masalah satu sama lain, belajar memberikan saran dengan baik dan menerima saran dari orang lain, belajar menerima, belajar bersyukur dari pengalaman yang kurang meyenenangkan sehingga akan tercapai hidup yang sejahtera meski dalam kondisi kesehatan yang kurang optimal.

4. Efektivitas intervensi Group Positive Psychotherapy ini tidak hanya sebatas pada perubahan sudut pandang ataupun belief serta perubahan skor pada aspek-aspek yang terkait namun juga perubahan perilaku secara nyata dan 
pengembangan diri ke arah yang lebih baik.

\section{Saran}

\section{Bagi Psikolog/ Terapis}

Bagi para psikolog dan atau terapis, dalam praktik klinis dapat memberikan group positive psychotherapy kepada penderita SLE ataupun bagi penderita sakit kronis yang lain dengan memodifikasi kegiatan, latihan dan tugas rumah yang diberikan. Hal ini agar terapi yang diberikan dapat disesuaikan dengan kondisi dan kebutuhan dari subjek/ partisipan. Salah satunya adalah tugas-tugas yang membutuhkan pemahaman sehingga bahsa yang digunakan lebih disederhanakan beserta dengan tugastugasnya supaya lebih mudah dimengerti oleh subjek yang mengikuti.

\section{Bagi Subjek Penelitian}

Diharapkan para subjek/ partisipan dapat menerapkan hal-hal yang sudah diajarkan selama proses terapi dan konsisten untuk terus dilakukan. Subjek/ partisipan penelitian juga diharapkan dapat mempertahankan komunikasi yang sudah terjalin bersama dan keakraban di dalam kelompok untuk tetap saling mendukung, dan sebagai tempat untuk saling berbagi.

\section{Bagi Komunitas Terkait}

Melihat adanya manfaat dari group positive psychotherapy, maka kepada komunitas terkait dalam hal ini khususnya "panggonkupu" dan juga komunitas lupus lainnya, disarankan untuk dapat menerapkan terhadap para odapus lainnya. Misalnya dilakukan sebagai kegiatan rutin komunitas sehingga semua anggota dapat mendapatkan manfaatnya.

\section{Bagi Peneliti Selanjutnya}

4.1. Peneliti selanjutnya dapat melakukan studi efektivitas dengan menggunakan jumlah subjek/ partisipan yang lebih besar jika akan dilakukan dalam bentuk kelompok, sehingga fungsi kelompok dapat bermanfaat secara optimal.

4.2. Bagi peneliti selanjutnya yang ingin melakukan terapi dengan menggunakan subjek/ partisipan kepada pasien atau orang yang sakit secara fisik dengan kondisi kesehatan yang tidak bisa diprediksi, diharapkan dapat membuat antisipasi terkait gugurnya subjek.

4.3. Peneliti selanjutnya dapat memperkaya pembahasan terkait dengan kondisi biologis odapus sebelum dan setelah diberikannya intervensi, melalui kontrol laboratorium yang lebih ketat, misalnya terkait dengan hormon dan aspek lain yag berkaitan.

4.4. Peneliti selanjutnya dapat melakukan monitoring tambahan dengan jangka waktu yang lebih lama sehingga dapat melihat efek dari terapi untuk jangka panjang.

\section{DAFTAR PUSTAKA}

Bieling, PeterJ., McCabe, Randi E., \& Antoni, Martin M. (2006). Cognitive Behavioral Therapy in Groups. New York: The Guilford Press

Butler. J., \& Kern, M. (2016). The PERMA-Profiler: A brief multidimensional measure of flourishing. Retrieved from http://www.peggykern.org/questio nnaires.html

Creswell, John W. Research Design: Qualitative, Quantitative, and Mixed Method Approaches $3^{\text {rd }}$ Ed. (2010). California: Sage Publication

Cronbach,L.L. (1993). Essentials of Psychological Testing. New York: Harper \& Row Publisher, Inc 
Diener,Ed. (2009). Assesing Well-being: The Colected Works of Ed Diener. New York:Springer

Huppert, F. A. (2009). Psychological Well-being: Evidence Regarding its Causes and Consequences. EJournal compilation International Association of Applied Psychology: Health and WellBeing. Retrieved from http://onlinelibrary.wiley.com/doi/ $10.1111 / \mathrm{j} .1758$ 0854.2009.01008.x/full.

Huppert, Felicia A., Timothy. (2013). Floirishing Across Europe: Application of a New Conceptual Framework for Defining Well Being. E-Journal of Well Being Institute \& Departeent, University of Cambridge, Soc Indic Res. Retrieved from https://www.ncbi.nlm.nih.gov/pm c/articles/PMC3545194/

Kementrian Kesehatan Republik Indonesia. (2017). E-Journal online. Retrieved from http://www.kemkes.go.id/

Kim, Jeong Han., Berven, Norman L., Chan, Fong., Gonzalez, Rene., Miller, Deborah J., \& Keck, Phillip S. (2011). Virtues in Relation to Subjective Well-Being for People With Chronic Illness and Disability, E-Journal of Asia Pacific Counseling. Retrieved from

210.101.116.28/W_files/kiss5/2f6 00760_pv.pdf

\footnotetext{
Magyar-Moe, Jeana L.(2009). Therapist's Guide to Positive Psychological Intervention. New York: Academic Press
}

Moleong, L.J. (2011). Metode Penelitian Kualitatif. Bandung: Rosdakarya

Navarrete-Navarrete, N., PeraltaRamirez, M.I., Sabio, J.M., Martinez-Egea, I., Santos-Ruiz, A., \& Jimenez-Alonso, J. (2010). Quality-of-life predictor factors in patients with sle and their modification after cognitive behavioural therapy. E-Journal online. Retrieved from https://www.ncbi.nlm.nih.gov/pub $\mathrm{med} / 20841339$

New York State Department of Health. (2008). Systemic Lupus erythematosus. New York: Author.

Park, N., Peterson, C., \& Seligman, M. E. (2009). Strengths of character and well-being. Journal of Social and Clinical Psychology, 23(5), 603-619. Retrieved from 209197-41-

56.unassigned.ntelos.net/...Psycho logy.../Strengths_of_Character Well

Pusat Data dan Informasi Kementrian Kesehatan RI Situasi Lupus di Indonesia. (2017). Retrieved from http://www.depkes.go.id/resource s/download/pusdatin/ infodatin/Infodatin-Lupus2017.pdf

Rashid, T., \& Seligman, M. (2018). Positive Psychotheray: Clinician Manual. New York : Oxford University Press 
Schattner, E., Shahar, G., Lerman, S., \& Shakra, M. A. (2010). Depression in Systemic Lupus Erythematosus: The key role of illness intrusiveness and concealment of symptoms. Psychiatry: Interpersonal \& Biological Processes, 73, 329340.

doi:10.1080/14681990410001715 427

Seligman, M. E. P. 2011. Flourish. New York, NY: Simon \& Schuster.

SIRS Onlien Direktorat Jenderal Pelayanan Kesehatan. (2016). Retrieved from http://sirs.yankes.kemkes.go.id/s irs/login.php

Sugiyono. (2012). Metode Penelitian Kuantitatif, Kualitatif, Dan $R$ \& $D$. Bandung : Alfabeta.

Sutisna, Dea C. (2010). Strategi Coping terhadap Stres akibat Penyakit Lupus pada Wanita Penderita Lupus. Skripsi Sarjana. Universitas Katolik Soegijapranata Semarang.

Wallace, D. J. (2007). The lupus book: Panduan lengkap bagi penderita lupus dan keluarganya. Yogyakarta: B-First.

Yayasan Lupus Indonesia. (2011). Retrieved from http://yayasanlupusindonesia. org/ 